\title{
KARAKTERISTIK PAPAN PARTIKEL KULIT BUAH KAKAO (Theobroma cacao L.) PADA VARIASI KONSENTRASI PEREKAT POLYVINYL ACETATE
}

\author{
I Gusti Made Teddy Pradana르, Bambang Admadi Harsojuwono², Amna Hartiati² \\ ${ }^{1}$ Mahasiswa Jurusan Teknologi Industri Pertanian, Fakultas Teknologi Pertanian Unud \\ ${ }^{2}$ Dosen Teknologi Industri Pertanian, Fakultas Teknologi Pertanian Unud \\ Kampus Bukit Jimbaran, Badung, Bali \\ E-mail: kontak@teddypradana.com ${ }^{1}$ \\ E-mail koresponden: bambang.admadi@unud.ac.id ${ }^{2}$
}

\begin{abstract}
The aims of this study were to know the characteristic of particle board cocoa-pod husk on variation of polyvinyl acetate (PVAc) adhesive concentration, and to have the best concentration polyvinyl acetate adhesive in particle board from cocoa-pod husk. The experiments in this study used a single factor with regression analysis. The factors are the concentration of polyvinyl acetate adhesive, that is $35 \%, 37.5 \%, 40 \%, 42.5 \%, 45 \%$ dan $47.5 \%$. The fisis test results showed that concentration of polyvinyl acetate adhesive had upward trend on density and downward trend on moisture content, water absorption, and thickness swelling. The mechanical test result showed that concentration of polyvinyl acetate adhesive on concentration $47.5 \%$ had the best treatment. The best treatmest of particle board from cocoa-pod husk is made by used $47.5 \%$ polyvinyl acetate adhesive with density $0.48 \mathrm{~g} / \mathrm{cm}^{3}$, moisture content $8,64 \%$, water absorption $155.85 \%$, thickness swelling $13.34 \%$ in fisis test and with MOE $44.07 \mathrm{~kg} / \mathrm{cm}^{2}$, MOR $1.38 \mathrm{~kg} / \mathrm{cm}^{2}$ and compressive strength parallel $2.36 \mathrm{~kg} / \mathrm{cm}^{2}$ in mechanical test.
\end{abstract}

Key words: particle board, cocoa-pod husk, polyvinyl acetate

\section{PENDAHULUAN}

Tanaman kakao adalah tanaman perkebunan yang populer ditanam di Indonesia. Menurut data Direktorat Jenderal Perkebunan, Kementerian Pertanian (2015), pada tahun 2014, Indonesia memiliki total luasan perkebunan kakao seluas 1.727 .437 ha yang terdiri dari perkebunan rakyat, kepemilikan perusahaan swasta dan pemerintah. Dengan luasan perkebunan kakao tersebut Indonesia mampu memproduksi kakao sebanyak 728.414 ton per tahun atau sekitar 2 ton per hektar per tahun. Hal ini dikuatkan dengan pusat data dan sistem informasi pertanian, Kementerian Pertanian (2016) mengenai outlook kakao yang menyatakan bahwa Indonesia merupakan negara penghasil kakao terbesar ke-2 di dunia setelah Pantai Gading.

Areal perkebunan yang semakin luas akan menghasilkan produksi kakao yang semakin banyak. Hal ini juga akan mengakibatkan jumlah limbah kulit buah kakao semakin tinggi. Secara fisis, berat kulit kakao bekisar 70-75\% dari keseluruhan berat buah kakao atau setiap ton buah kakao akan menghasilkan $700 \mathrm{~kg}$ sampai dengan $750 \mathrm{~kg}$ kulit buah kakao (Cruz et al. 2012).

Kulit buah kakao mengandung bahan berserat tinggi (40\%) dengan kadar protein rendah 7-10 persen (Smith and Adegbola, 1977 dalam Laconi, 1998). Serat pada kulit buah kakao mengandung komponen utama berupa lignin, selulosa dan hemiselulosa (Anas, 2011 dalam Purnamawati dan Utami, 2014). Menurut Daud et al. (2013), kulit buah kakao mengandung 74\% holoselulosa, 35,4\% selulosa, $37 \%$ hemiselulosa dan $14,7 \%$ lignin.

Pemanfaatan limbah kulit buah kakao masih sangat terbatas untuk pakan ternak dan pupuk. Sebagai pakan ternak, kulit buah kakao memerlukan proses awalan fermentasi untuk meningkatkan kandungan protein menjadi 15-17\% dan serta menurunkan serat kasar 10-11\% (Guntoro et al., 2002). 
Namun, walaupun telah difermentasi, kandungan protein kulit kakao tidak memasuki standar konsentrat pakan ternak, sehingga pemanfaatannya lebih kepada penggunaannya sebagai pupuk. Dalam penelitian Astria dan Suntari (2017), ketersediaan N, P, K terbaik dalam tanah yang diuji cobakan pada tanaman sawi menunjukan perlakuan terbaik pada penambahan kulit kakao sebanyak 25\% pada urea. Rendahnya penggunaan kulit buah kakao mengakibatkan sebagian besar limbah kulit buah kakao yang dihasilkan hanya dibiarkan membusuk begitu saja di sekitar area perkebunan (Purnamawati dan Utami, 2014).

Kandungan lignoselulosa pada serat kulit buah kakao berpotensi dimanfaatkan sebagai bahan baku pembuatan papan partikel. Penelitian sebelumnya, Hendronursito (2015) dalam penelitiannya mengungkapkan bahwa penambahan 130 gram PVAc dengan 400 gram partikel akar alang-alang menghasilkan papan partikel yang memenuhi Standar Nasional Indonesia (SNI) tentang papan partikel. Penelitian tersebut menunjukkan kerapatan papan partikel dari akar alang-alang adalah rata-rata sebesar $0,87 \mathrm{~g} / \mathrm{cm}^{3}$, kadar air $10,6 \%$ dan pengembangan tebal $8,6 \%$.

Pembuatan papan partikel dengan bahan baku limbah kulit buah kakao masih belum pernah diteliti, terlebih dengan menggunakan konsentrasi perekat tertentu. Berdasarkan hal tersebut, perlu dilakukan penelitian lebih lanjut, guna untuk mengetahui karasteristik papan partikel dari kulit kakao pada konsentrasi bahan perekat tertentu.

\section{METODE PENELITIAN}

\section{Tempat dan Waktu}

Penelitian ini dilaksankan di Laboratorium Teknologi Pasca Panen, Fakultas Teknologi Pertanian Universitas Udayana dan Laboratorium Daya dan Mesin Pertanian, Jurusan Teknik Pertanian Universitas Brawijaya, Malang. Waktu pelaksanaan September hingga Desember 2017.

\section{Bahan dan Alat}

Bahan-bahan yang digunakan dalam penelitian ini terdiri yaitu kulit buah kakao (Theobroma cacao L.) yang diperoleh dari Desa Lalanglinggah, Kabupaten Tabanan, Bali dan perekat polyvinyl acetate (Rajawali). Bahan pendukung penelitian yaitu aluminium foil, tissue dan kertas label.

Peralatan yang digunakan dalam penelitian ini yaitu penumbuk, baskom, kotak cetakan 30x30x6cm, ayakan 56 dan 60 mesh, oven, timbangan digital, keramik (sebagai tekanan), gergaji, jangka sorong, peralatan uji mekanis papan partikel berdasarkan ASTM.

\section{Rancangan Penelitian}

Penelitian dilakukan dengan mencoba beberapa konsentrasi perekat dalam pembuatan papan partikel kulit buah kakao. Rancangan ini merupakan percobaan faktorial dengan satu faktor, yaitu konsentrasi perekat polyvinyl acetate (PVAc), terdiri dari konsentrasi perekat 35,0\%, 37,5\%, 40,0\%, 42,5\%, 45,0\%, 47,5\%. Masing-masing perlakuan dilakukan sebanyak 3 kali berdasarkan waktu pengerjaannya sehingga diperoleh 18 satuan percobaan. Data yang diperoleh selanjutnya diolah hubungannya secara regresi sehingga diperoleh persamaan regresi dan korelasi antara variabel yang diuji dengan konsentrasi perekat PVAc. 


\section{Pelaksanaan Penelitian}

\section{Persiapan Bahan Kulit Buah Kakao}

Kulit buah kakao yang telah dipisahkan dengan biji buah kakao dilakukan pengecilan ukuran 3$5 \mathrm{~cm}$ pada setiap potongan kulit buah kakao. Selanjutnya dijemur di bawah sinar matahari hingga kulit kakao kering atau memiliki kadar air di bawah 15\%. Setelah kulit kakao kering kemudian dihaluskan dengan cara di tumbuk hingga berbentuk serbuk. Terakhir bubuk di saring menggunakan 2 buah ayakan ukuran 56 mesh dan 60 mesh untuk memperoleh bubuk kulit buah kakao dengan ukuran homogen. Serbuk kulit buah kakao yang digunakan adalah yang lolos ayakan 56 mesh dan tidak lolos ayakan 60 mesh.

\section{Proses Pembuatan Papan Partikel Kulit Buah Kakao}

Pembuatan papan partikel kulit buah kakao dilakukan dengan menambah perekat sesuai perlakuan dengan bahan dasar bubuk kulit buah kakao sebanyak 400 gram. Sebelum dicampur, perekat ditambahkan terlebih dahulu dengan air sebanyak $2 \mathrm{ml}$. Perekat yang ditambahkan dipastikan tercampur merata pada setiap patikel bahan. Selanjutnya campuran perekat dan bubuk kulit buah kakao yang telah homogen ditempatkan pada pencetak berukuran $30 \times 30 \times 6 \mathrm{~cm}$, sehingga tinggi adonan papan partikel 1 $\mathrm{cm}$. Adonan papan partikel yang telah ditempatkan pada cetakan selanjutnya diberikan tekanan $10 \mathrm{~g} / \mathrm{cm}^{2}$ selama 4 jam pada suhu $55^{\circ} \mathrm{C}$ dalam oven pengering. Selanjutnya tekanan (beban) yang diberikan pada papan partikel dilepaskan, dan dioven kembali selama 4 jam dalam suhu $55^{\circ} \mathrm{C}$ agar papan partikel kering merata. Setelah papan partikel dioven, pengerjaan akhir dilakukan dengan pemotongan pinggiran agar rapi dan penampakan papan partikel telihat homogen.

\section{Variabel yang Diamati}

Variabel yang diarnati adalah sifat fisis dan mekanis pada papan partikel. Uji fisis meliputi kerapatan, kadar air, daya serap air dan pengernbangan tebal. Uji mekanis yang terdiri dari modulus young/modulus elastisitas (MOE) keteguhan lengkung statik/modulus of repture (MOR) dan keteguhan tekan sejajar.

\section{HASIL DAN PEMBAHASAN}

\section{Sifat Fisis}

Kerapatan

Hasil analisis regresi menunjukkan bahwa persamaan regresi antara konsentrasi perekat PVAc dengan kerapatan papan partikel kulit buah kakao ditunjukan dalam persamaan $y=0,01 x+0,17$ dengan nilai korelasi $r=0,96$ dan determinasi $r^{2}=0,92$. Rata-rata kerapatan papan partikel kulit buah kakao dapat dilihat pada Gambar 2. 


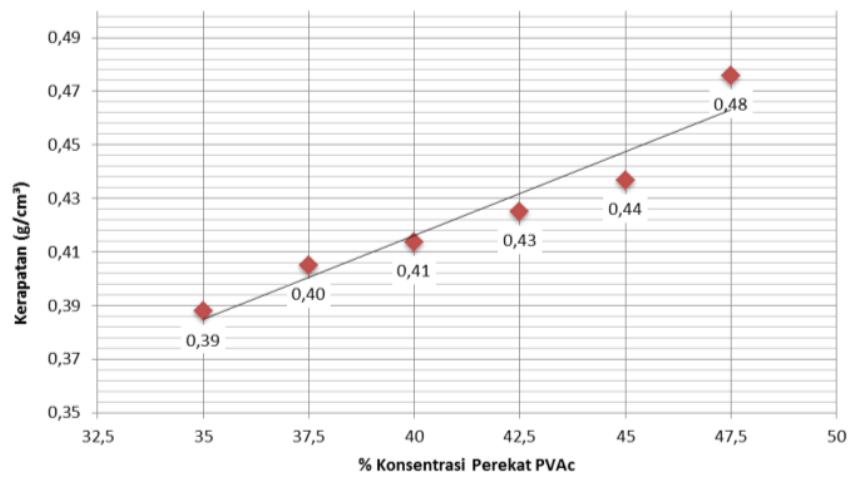

Gambar 2. Nilai rata-rata kerapatan papan partikel kulit buah kakao $\left(\mathrm{g} / \mathrm{cm}^{3}\right)$.

Gambar 2 menunjukkan tren meningkat antara konsentrasi perekat PVAc dengan kerapatan papan partikel kulit buah kakao. Nilai korelasi (r) sebesar 0,96 menunjukkan bahwa hubungan yang sangat kuat antara konsentrasi perekat PVAc dengan kerapatan papan partikel kulit buah kakao. Penambahan konsentrasi perekat PVAc juga akan menambah konsentrasi kerapatan papan partikel kulit buah kakao dengan persamaan $\mathrm{y}=0,01 \mathrm{x}+0,17$. Nilai determinasi $\left(\mathrm{r}^{2}\right)$ sebesar 0,92 menunjukkan bahwa $92 \%$ kerapatan papan partikel kulit buah kakao dipengaruhi oleh konsentrasi perekat PVAc.

Perlakuan dengan konsentrasi perekat 47,5\% menghasilkan kerapatan papan partikel kulit buah kakao yang tertinggi dibandingkan dengan perlakuan konsentrasi perekat PVAc lainnya sebesar 0,48 $\mathrm{g} / \mathrm{cm}^{3}$. Sedangkan perlakuan dengan konsentrasi perekat 35,0\% menghasilkan kerapatan papan partikel kulit buah kakao yang terendah sebesar $0,39 \mathrm{~g} / \mathrm{cm}^{3}$. Kerapatan dari perlakuan konsentrasi perekat 47,5\% lebih tinggi karena jumlah perekat yang lebih banyak, secara fisis akan lebih mampu mengikat partikelpartikel serbuk kulit buah kakao melalui rongga-rongga yang diisinya (Mawardi, 2009). Dalam penelitian ini, selain perlakuan dengan konsentrasi perekat PVAc 35,0\%, seluruh perlakuan telah memenuhi standar SNI 03-2015-2006.

\section{Kadar Air}

Hasil analisis regresi menunjukkan bahwa persamaan regresi antara konsentrasi perekat PVAc dengan kadar air papan partikel kulit buah kakao ditunjukan dalam persamaan $\mathrm{y}=-0,12 \mathrm{x}+14,34$ dengan nilai korelasi $r=0,99$ dan determinasi $r^{2}=0,99$. Rata-rata kadar air papan partikel kulit buah kakao dapat dilihat Gambar 3.

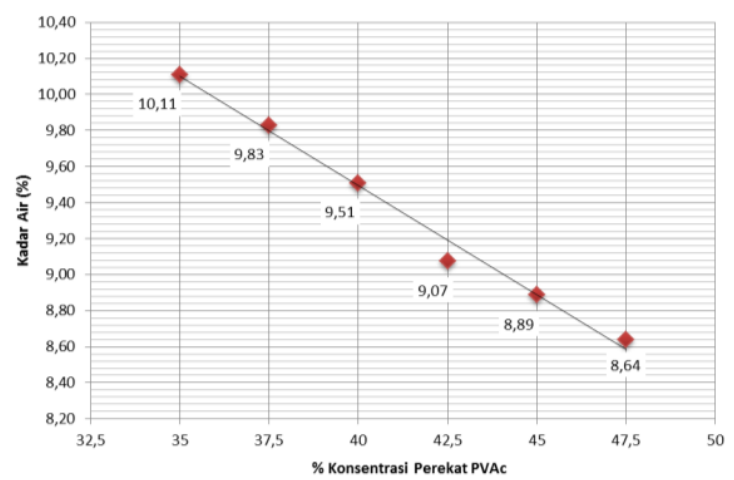

Gambar 3. Nilai rata-rata kadar air papan partikel kulit buah kakao (\%) 
Gambar 3 menunjukkan tren menurun antara konsentrasi perekat PVAc dengan persentase kadar air papan partikel kulit buah kakao. Nilai korelasi (r) sebesar 0,99 menunjukkan bahwa hubungan yang sangat kuat antara konsentrasi perekat PVAc dengan kadar air papan partikel kulit buah kakao. Penambahan konsentrasi perekat PVAc akan menurunkan kadar air papan partikel kulit buah kakao dengan persamaan $\mathrm{y}=-0,12 \mathrm{x}+14,34$. Nilai determinasi $\left(\mathrm{r}^{2}\right)$ sebesar 0,99 menunjukkan bahwa $99 \%$ persentase kadar air papan partikel kulit buah kakao dipengaruhi oleh konsentrasi perekat PVAc.

Perlakuan dengan konsentrasi perekat 47,5\% menghasilkan kadar air papan partikel kulit buah kakao yang terendah dibandingkan dengan perlakuan konsentrasi perekat PVAc lainnya sebesar 8,64\%. Sedangkan perlakuan dengan konsentrasi perekat 35,0\% menghasilkan kadar air papan partikel kulit buah kakao yang tertinggi sebesar 10,11\%. Bila dibandingkan dengan kadar air bahan baku serbuk kulit buah kakao yaitu sebesar 15\% dengan hasil pengujian kadar air papan partikel kulit buah kakao pada semua perlakuan menunjukkan nilai kadar air yang lebih rendah. Hal ini sesuai dengan Massijaya et al. (2005) yang menyatakan umumnya kadar air papan partikel lebih rendah dari kadar air bahan bakunya. Hal ini terjadi sebagai akibat dari perlakuan panas yang diterima papan partikel kayu pada saat pemberian tekanan dan suhu yang tinggi. Kadar air dari perlakuan konsentrasi perekat 47,5\% lebih rendah karena jumlah perekat yang lebih banyak, secara fisis akan menutupi rongga partikel dengan lebih sempurna dan tidak mudah terhidrolisis (Mawardi, 2009). Kadar air seluruh perlakuan menunjukkan telah memenuhi standar SNI 03-2015-2006.

\section{Daya Serap Air}

Hasil analisis regresi menunjukkan bahwa persamaan regresi antara konsentrasi perekat PVAc dengan kadar air papan partikel kulit buah kakao ditunjukan dalam persamaan $y=-2,26 x+260,98$ dengan nilai korelasi $r=0,97$ dan determinasi $r^{2}=0,94$. Rata-rata daya serap air papan partikel kulit buah kakao dapat dilihat Gambar 4.

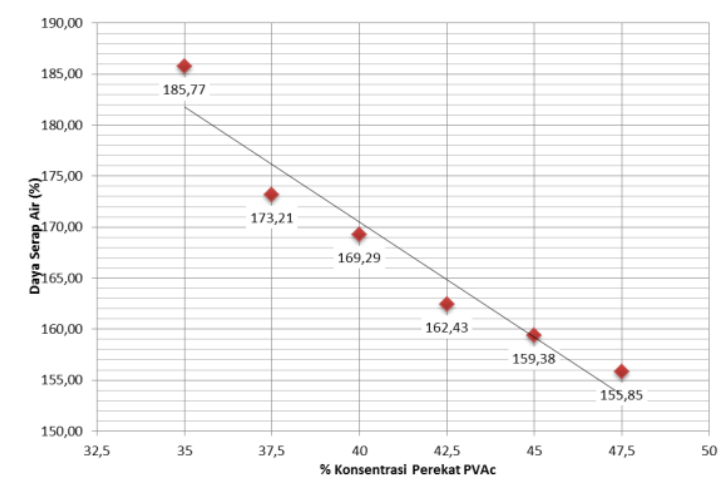

Gambar 4. Nilai rata-rata daya serap air papan partikel kulit buah kakao (\%).

Gambar 4 menunjukkan tren menurun antara konsentrasi perekat PVAc dengan persentase daya serap air papan partikel kulit buah kakao. Nilai korelasi (r) sebesar 0,97 menunjukkan bahwa hubungan yang sangat kuat antara konsentrasi perekat PVAc dengan daya serap air papan partikel kulit buah kakao. Penambahan konsentrasi perekat PVAc akan menurunkan daya serap air papan partikel kulit buah kakao dengan persamaan y $=-2,26 x+260,98$. Nilai determinasi $\left(r^{2}\right)$ sebesar 0,94 menunjukkan bahwa $94 \%$ persentase daya serap air papan partikel kulit buah kakao dipengaruhi oleh konsentrasi perekat PVAc. 
Perlakuan dengan konsentrasi perekat 47,5\% menghasilkan kadar air papan partikel kulit buah kakao yang terendah dibandingkan dengan perlakuan konsentrasi perekat PVAc lainnya sebesar 155,85\%. Sedangkan perlakuan dengan konsentrasi perekat 35,0\% menghasilkan daya serap air papan partikel kulit buah kakao yang tertinggi sebesar $185,77 \%$. Nilai daya serap air dipengaruhi oleh kerapatan. Semakin tinggi konsentrasi perekat PVAc yang diberikan terhadap papan partikel, maka kerapatannya juga akan semakin tinggi yang mengakibatkan daya serap airnya semakin rendah. Hal ini disebabkan papan partikel yang memiliki kerapatan yang tinggi memiliki sedikit rongga yang dapat diisi oleh air. Hal ini sesuai dengan pernyataan Sutigno (1994) bahwa semakin tinggi kerapatan papan partikel, ada kecenderungan penyerapan airnya semakin rendah. Maloney (1993) menyatakan semakin tinggi densitas (kerapatan) papan, maka ikatan antar partikel semakin kompak sehingga rongga udara dalam lembaran papan mengecil. Keadaan ini menyebabkan air atau uap air menjadi sulit untuk mengisi rongga tersebut. Ini berarti, semakin kecil densitas maka daya serap air akan semakin besar. Dalam SNI 03-2015-2006 tidak menetapkan standar untuk daya serap air, tetapi perlu dilakukan pengujiannya untuk mengetahui ketahanan papan terhadap air dan dalam penggunaannya.

\section{Pengembangan Tebal}

Hasil analisis regresi menunjukkan bahwa persamaan regresi antara konsentrasi perekat PVAc dengan pengembangan tebal papan partikel kulit buah kakao ditunjukan dalam persamaan $\mathrm{y}=-0,53 \mathrm{x}+$ 38,14 dengan nilai korelasi $r=0,99$ dan determinasi $r^{2}=0,99$. Rata-rata pengembangan tebal papan partikel kulit buah kakao dapat dilihat pada Gambar 5.

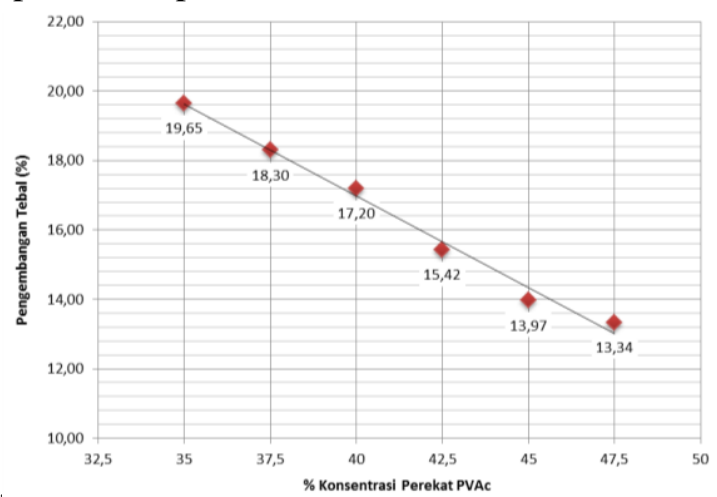

Gambar 5. Nila1 rata-rata pengembangan tebal papan partıkel kulit buah kakao (\%).

Pengembangan tebal merupakan perubahan dimensi tebal papan setelah direndam selama waktu tertentu. Pengembangan tebal papan partikel terjadi karena partikel memiliki sifat yang mampu melepaskan dan mengikat air (higroskopis). Menurut Tsoumis (1991) pengembangan dan penyusutan volume kayu dipengaruhi oleh banyak faktor seperti kadar air, kerapatan, struktur anatomi, ekstraktif, dan komposisi kimia. Gambar 5 menunjukkan tren menurun antara konsentrasi perekat PVAc dengan persentase pengembangan tebal papan partikel kulit buah kakao. Nilai korelasi (r) sebesar 0,99 menunjukkan bahwa hubungan yang sangat kuat antara konsentrasi perekat PVAc dengan daya serap air papan partikel kulit buah kakao. Penambahan konsentrasi perekat PVAc akan menurunkan pengembangan tebal papan partikel kulit buah kakao dengan persamaan $\mathrm{y}=-0,53 \mathrm{x}+38,14$. Nilai 
determinasi $\left(\mathrm{r}^{2}\right)$ sebesar 0,99 menunjukkan bahwa 99\% persentase pengembangan tebal papan partikel kulit buah kakao dipengaruhi oleh konsentrasi perekat PVAc.

Perlakuan dengan konsentrasi perekat 47,5\% menghasilkan pengembangan tebal papan partikel kulit buah kakao yang terendah dibandingkan dengan perlakuan konsentrasi perekat PVAc lainnya sebesar 13,34\%. Sedangkan perlakuan dengan konsentrasi perekat 35,0\% menghasilkan pengembangan tebal papan partikel kulit buah kakao yang tertinggi sebesar 19,65\%. Hal ini disebabkan oleh ikatan antar partikel lebih rapat pada perlakuan konsentrasi perekat PVAc yang lebih tinggi, sehingga air yang masuk ke dalam papan partikel menjadi lebih sedikit dan pengembangan tebalnya menjadi menurun. Bowyer et al. (2003) menerangkan bahwa semakin banyak perekat yang digunakan dalam pembuatan papan maka dimensi papan yang dihasilkan akan semakin stabil. Pengembangan tebal papan partikel kulit buah kakao pada semua perlakuan belum mampu memenuhi standar SNI 03-2015-2006 karena nilai pengembangan tebal yang dihasilkan masih diatas $12 \%$. Nilai persentase pengembangan tebal yang tinggi dapat disebabkan oleh tidak optimalnya proses pengempaan panas (pemberian tekanan dan suhu) yang dilakukan saat mencetak papan partikel kulit buah kakao.

\section{Sifat Mekanis}

\section{Modulus Young/Modulus of Elasticity (MOE)}

Hasil pengujian mekanis menunjukkan bahwa perlakuan konsentrasi perekat PVAc menghasilkan nilai rata-rata Modulus of Elasticity papan partikel kulit buah kakao yang dapat dilihat pada Tabel 1.

Tabel 1. Nilai rata-rata MOE papan partikel kulit buah kakao (\%)

\begin{tabular}{cc}
\hline Konsentrasi Perekat PVAc & Rata-rata MOE \\
\hline PA1 $(35 \%)$ & $\mathrm{Tt}$ \\
PA2 $(37,5 \%)$ & $\mathrm{Tt}$ \\
PA3 $(40 \%)$ & $\mathrm{Tt}$ \\
PA4 $(42,5 \%)$ & $\mathrm{Tt}$ \\
PA5 $(45 \%)$ & $32,83 \pm 1,66$ \\
PA6 (47,5\%) & $44,07 \pm 1,44$ \\
\hline
\end{tabular}

Keterangan: $\mathrm{Tt}=$ tidak terditeksi

Modulus of elastisity (MOE) atau modulus elastisitas merupakan sifat mekanis yang menunjukkan sifat ketahanan papan partikel terhadap pembebanan dalam batas proporsi sebelum terjadi patah. Nilai keteguhan lentur dinyatakan dalam $\mathrm{kg} / \mathrm{cm}^{2}$. Pada Tabel 1 menunjukkan perlakuan dengan konsentrasi perekat 47,5\% menghasilkan nilai MOE tertinggi yaitu 44,07 kg/ $\mathrm{cm}^{2}$ dan terendah yang mampu dibaca oleh alat yaitu pada konsentrasi 45,0\% dengan nilai MOE 32,83 kg/cm 2 . Perlakukan dengan konsentrasi perekat 35,0\%, 37,5\%, 40,0\% dam 42,5\% tidak terditeksi karena memiliki nilai yang lebih rendah dari skala nilai minimal alat pengujian. Hal ini disebabkan oleh rendahnya konsentrasi perekat pada papan partikel dan luasnya permukaan serbuk kulit buah kakao sehingga pendistribusian perekat PVAc pada permukaan serbuk kulit buah kakao menjadi tidak merata, seperti halnya pada serbuk gergaji. Menurut Okai et al. (2004) dan Bowyer et al. (2003) bahwa serbuk gergaji memiliki permukaan bidang rekat yang luas sehingga distribusi perekat menjadi kurang merata sempurna. Akibatnya saat 
dilakukan pengujian MOE, papan partikel tidak sanggup menahan beban uji. Nilai MOE dari papan partikel kulit buah kakao ini belum memenuhi standar SNI 03-2015-2006 tentang papan partikel.

\section{Keteguhan Lengkung Statik/Modulus of Repture (MOR)}

Hasil pengujian mekanis menunjukkan bahwa perlakuan konsentrasi perekat PVAc menghasilkan nilai rata-rata keteguhan lengkung statik/modulus of repture (MOR) papan partikel kulit buah kakao yang dapat dilihat pada Tabel 2.

Tabel 2. Nilai rata-rata MOR papan partikel kulit buah kakao (\%)

\begin{tabular}{cc}
\hline Konsentrasi Perekat PVAc & Rata-rata MOR \\
\hline PA1 $(35 \%)$ & $\mathrm{Td}$ \\
PA2 $(37,5 \%)$ & $\mathrm{Td}$ \\
PA3 $(40 \%)$ & $\mathrm{Td}$ \\
PA4 $(42,5 \%)$ & $\mathrm{Td}$ \\
PA5 $(45 \%)$ & $0,65 \pm 0,11$ \\
PA6 $(47,5 \%)$ & $1,38 \pm 0,06$ \\
\hline
\end{tabular}

Keterangan: $\mathrm{Tt}=$ tidak terditeksi

Modulus of Repture (MOR) atau keteguhan lengkung statis adalah tingkat keteguhan papan partikel dalam menerima beban tegak lurus terhadap permukaan papan. Nilai keteguhan patah dinyatakan dalam $\mathrm{kg} / \mathrm{cm}^{2}$. Pada Tabel 2 menunjukkan perlakuan dengan konsentrasi perekat 47,5\% menghasilkan nilai MOR tertinggi yaitu $1,38 \mathrm{~kg} / \mathrm{cm}^{2}$ dan terendah yang mampu dibaca oleh alat yaitu pada konsentrasi 45,0\% dengan nilai MOR 0,65 kg/ $\mathrm{cm}^{2}$. Perlakukan dengan konsentrasi perekat 35,0\%, 37,5\%, 40,0\% dan $42,5 \%$ tidak terditeksi karena memiliki nilai yang lebih rendah dari perlakuan 45,0\%, sehingga tidak terbaca oleh alat. Hal ini disebabkan oleh rendahnya konsentrasi perekat pada papan partikel dan luasnya permukaan serbuk kulit buah kakao sehingga pendistribusian perekat PVAc pada permukaan serbuk kulit buah kakao menjadi tidak merata, seperti halnya pada serbuk gergaji. Menurut Okai et al. (2004) dan Bowyer et al. (2003) bahwa serbuk gergaji memiliki permukaan bidang rekat yang luas sehingga distribusi perekat menjadi kurang merata sempurna. Akibatnya saat dilakukan pengujian MOR, papan partikel tidak sanggup menahan beban uji. Nilai MOR dari papan partikel kulit buah kakao ini belum memenuhi standar SNI 03-2015-2006 tentang papan partikel.

\section{Keteguhan Tekan Sejajar}

Hasil pengujian mekanis menunjukkan bahwa perlakuan konsentrasi perekat PVAc menghasilkan nilai rata-rata keteguhan tekan sejajar papan partikel kulit buah kakao yang dapat dilihat pada Tabel 3 .

Tabel 3. Nilai rata-rata keteguhan tekan sejajar papan partikel kulit buah kakao (\%)

\begin{tabular}{cc}
\hline Konsentrasi Perekat PVAc & $\begin{array}{c}\text { Rata-rata } \\
\text { Keteguhan Tekan Sejajar }\end{array}$ \\
\hline PA1 $(35 \%)$ & $\mathrm{Td}$ \\
PA2 $(37,5 \%)$ & $\mathrm{Td}$ \\
PA3 $(40 \%)$ & $\mathrm{Td}$ \\
PA4 $(42,5 \%)$ & $0,39 \pm 0,05$ \\
PA5 $(45 \%)$ & $1,18 \pm 0,03$ \\
PA6 (47,5\%) & $2,36 \pm 0,15$ \\
\hline
\end{tabular}

Keterangan: $\mathrm{Tt}=$ tidak terditeksi 
Keteguhan tekan sejajar adalah tingkat keteguhan papan partikel dalam menerima beban dengan posisi papan partikel yang tegak lurus atau sejajar. Nilai keteguhan tekan sejajar dinyatakan dalam $\mathrm{kg} / \mathrm{cm}^{2}$. Pada Tabel 3 menunjukkan perlakuan dengan konsentrasi perekat 47,5\% menghasilkan nilai keteguhan tekan sejajar tertinggi yaitu $2,36 \mathrm{~kg} / \mathrm{cm}^{2}$ dan terendah yang mampu dibaca oleh alat yaitu pada konsentrasi $42,5 \%$ dengan nilai keteguhan tekan sejajar $0,39 \mathrm{~kg} / \mathrm{cm}^{2}$. Perlakukan dengan konsentrasi perekat 35,0\%,37,5\%, dan 40,0\% tidak terditeksi karena memiliki nilai yang lebih rendah dari perlakuan $42,5 \%$, sehingga tidak terbaca oleh alat.

Nilai keteguhan tekan sejajar yang semakin tinggi berbanding lurus dengan kerapatan papan partikel yang disebabkan oleh terikatnya secara merata partikel-partikel serbuk kulit buah kakao oleh perekat PVAc. Selain itu kadar air pada papan partikel membuat struktur partikel yang saling berikatan menjadi lebih stabil. Menurut Tsoumis (1991) sifat mekanis kayu dipengaruhi oleh beberapa faktor terutama kadar air, kerapatan, struktur, temperatur, lama pembebanan dan cacat. Walaupun keteguhan tekan sejajar tidak menjadi indikator standar dalam SNI 03-2015-2006, namun pengujian tetap perlu dilakukan untuk melihat pemerataan struktur ikatan partikel pada papan yang dibuat. Nilai keteguhan tekan sejajar yang semakin tinggi menunjukkan partikel-partikel dalam papan partikel kulit buah kakao lebih solid, sehingga dengan demikian papan partikel yang dibuat juga semakin tinggi kualitasnya.

\section{KESIMPULAN DAN SARAN}

\section{Kesimpulan}

1. Perlakuan variasi konsentrasi perekat PVAc menghasilkan karakteristik papan partikel kulit buah kakao yang berbeda. Penambahkan konsentrasi perekat PVAc mengakibatkan tren meningkat pada sifat papan partikel yaitu kerapatan, MOE, MOR dan keteguhan tekan sejajar serta memberikan tren menuruun pada kadar air, daya serap air dan pengembangan tebal.

2. Perlakuan terbaik untuk menghasilkan papan partikel kulit buah kakao adalah perlakuan dengan konsentrasi perekat PVAc 47,5\% dengan karakteristik sifat fisis kerapatan 0,48 g/ $\mathrm{cm}^{3}$, kadar air $8,64 \%$, daya serap air 155,85\%, pengembangan tebal 13,34\% dan sifat mekanis MOE 44,07 kg/ $\mathrm{cm}^{2}$, MOR $1,38 \mathrm{~kg} / \mathrm{cm}^{2}$, keteguhan tekan sejajar $2,36 \mathrm{~kg} / \mathrm{cm}^{2}$.

\section{Saran}

Penelitian lebih lanjut mengenai pembuatan papan partikel kulit buah kakao sangat perlu dilakukan. Penelitian pembuatan papan partikel kulit buah kakao dengan menggunakan perekat PVAc selanjutnya perlu memperhatikan ukuran mesh serbuk kulit kakao dan tekanan yang diberikan saat papan partikel di cetak dalam oven agar diperoleh karakteristik papan partikel yang lebih baik. Selain itu, penelitian selanjutnya dapat mempertimbangkan jenis perekat lain dari golongan thermosetting dan menggunakan proses kempa panas pada saat pencetakan agar menghasilkan papan partikel dengan sifat fisis dan mekanis yang memenuhi standar yang ditetapkan. 


\section{DAFTAR PUSTAKA}

Astria, P dan R. Suntari. 2017. Aplikasi Urea dan Kompos Kulit Kakao untuk Meningkatkan Ketersediaan dan Serapan N, P, K serta Produksi Tanaman Sawi pada Inceptisol Tulungrejo, Batu. Jurnal Tanah dan Sumberdaya Lahan. 4 (1): 453-461.

Bowyer, J.L., dan J.G. Haygreen. 2003. Hasil Hutan dan Ilmu Kayu: Suatu Pengantar (terjemahan). Gadjah Mada University Press, Yogyakarta.

Cruz, G., M. Pirila, M., Huuhtanen, L., Carrion, E., Alvarenga and R.L. Keiski, 2012. Production of Activated Carbon from Cocoa (Theobroma cacao L.) Pod Husk. Journal Civil and Environmental Engineering, 2(2): 1-6.

Daud, Z., Kassim, A.S.M., Aripin, A.M., Awang, H and M.Z.M Hatta. 2013. Chemical Composition and Morphological of Cocoa Pod Husks and Cassava Peels for Pulp and Paper Production. Australian Journal of Basic and Applied Sciences, 7(9): 406-411

Dewan Standarisasi Nasional. 2006. SNI 03-2015-2006 Mutu Papan Partikel. Standarisasi Nasional Indonesia. Jakarta.

Direktorat Jendral Perkebunan. Kernenterian Perkebunan. 2015. Statistik Perkebunan Indonesia 20142016. Jakarta.

Guntoro, S., Yasa, I.M.R., Sumawa I.N., Sumartini dan Rubiyo. 2002. Laporan Hasil Pengkajian Sistem Usaha Tani Ternak Kambing dengan Tanamanan Industri. Proyek Pengkajian Partisifatif Bali. Balai Pengkajian Teknologi Pertanian Bali.

Hendronursito, Y. 2015. Uji Fisis Papan Partikel Akar Alang-alang sesuai Standar SNI 03-2105-2006. Lernbaga Ilmu Pengetahuan Indonesia (LIPI). Jurnal Teknologi. 8(1): 37-43.

Laconi, A., 1998. Penggunaan Kulit Buah Kakao sebagai Pakan Ternak. Fakultas Peternakan, Institut Pertanian Bogor, Bandung.

Laconi, E.B. 1988. Peningkatan Mutu Pod Kakao Melalui Amoniasi dengan Urea dan Bio Fermentasi dengan Phanerrochaete chrysosporium serta Penjabarannya kedalam Formula Ransum Ruminansia. Tesis. Program Pasca Sarjana IPB, Bogor.

Maloney, T.M. 1993. Modern Particle Board and Dry Process Fibre Board Manufacturing. Miller Freeman Inc, San Fransisco.

Massijaya, MH., Hadi Y.S. dan H. Marsiah. 2005. Pemanfaatan Limbah Kayu dan Karton Sebagai Bahan Baku Papan Komposit. Laporan Penelitian Lembaga Penelitian dan Pemberdayaan Masyarakat.

Mawardi, I. 2009. Mutu Papan Partikel dari Kayu Kelapa Sawit (KKS) Berbasis Perekat Polystyrene. Jurnal Teknik Mesin Politeknik Negeri Hokseumawe Banda Aceh, 11(2): 12-14.

Okai R., Frimpong-Mensah K., Yeboah, D. 2004. Characterization of Strength Properties of Branchwood and Stemwood of Some Tropical Hardwood Species. Wood Scie and Tech, 38(2):97-99.

Purnamawati, H., Utami, B. 2014..Pemanfaatan Limbah Kulit Buah Kakao (Theobroma cacao L.) Sebagai Adsorben Zat Warna. Pendidikan Fisika PMIPA, Univesitas Sebelas Maret.

Pusat Data Sistem Informasi Pertanian. 2016. Outlook Komoditi Kakao. Kementrian Pertanian.

Sutigno, P. 1994. Teknologi Papan Partikel. Departemen Kehutanan Badan Penelitian dan Pengembangan Hasil Hutan dan Sosial Ekonomi Kehutanan, Bogor.

Tsoumis, G. 1991. Science and Technology of Wood: Structure, Properties, Utilization. University of Aristotelion, Thessaloniki, Greece. 